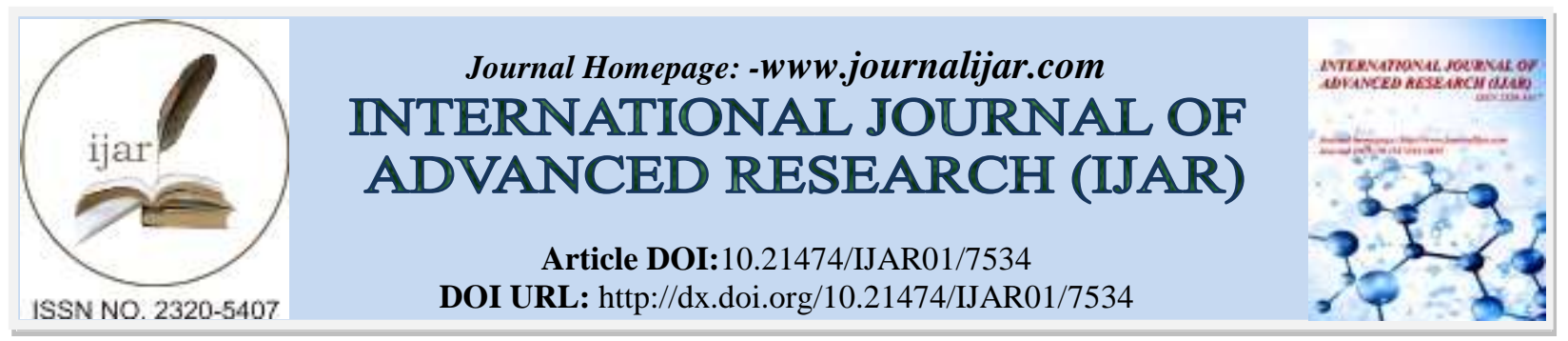

RESEARCH ARTICLE

\title{
COMPARATIVE ASSESSMENT OF LABORATORY PRODUCED AND COMMERCIALLY AVAILABLE COW URINE DISTILLATES.
}

Anil Kanaujia and Sarvesh Kumar Upadhyay.

Ayurvet Research Foundation-Research and Development Centre, Village, Chidana, Sonepat, Haryana.

\section{Manuscript Info}

Manuscript History

Received: 11 June 2018

Final Accepted: 13 July 2018

Published: August 2018

Keywords:-

Cow urine, distillates, in house prepared,

HPLC, TDS, panchgavya

\begin{abstract}
In ancient Ayurveda Gomutra (cow urine) has been greatly mentioned for its pharmacological importance. It is also an important component of the mixture called Panchagavya. Modern science has also proved its medicinal properties and role against antibiotic resistant bacteria. In India, there is demand of more than 5000 litres of distilled cow urine per day.As the cow urine distillate is mainly consumed as medicine to cure different ailments its quality and authenticity always remain questionable. A study was carried out to compare the urine's physico chemical parameters of indigenous and exotic cow breed, in house prepared cow urine distillate and market available products.
\end{abstract}

Copy Right, IJAR, 2018, All rights reserved.

\section{Introduction:-}

The medicinal importance of Gomutra (cow urine) is well described in Ayurveda. It is also an important component of the mixture called Panchagavya. Use of Panchgavya in preparing medicinal as well as domestic and agricultural products which are effective, eco-friendly, chemical free and harmless to human being will be a revolutionary step to combat pollution and health hazard. A number of studies conducted over the past few years have reported that gomutra is capable of curing blood pressure, blockage in arteries, arthritis, diabetes, cancer, thyroid, asthma, psoriasis, gynaecological, act as antiseptic etc. (Kishore et al., 2015) and has been found to enhance the bioavailability \& effectiveness ofantimicrobial, antifungal and anticancer drugs (Singla et al., 2016). Cow urine has a positive effect on plant growth (Mohanty et al., 2015) and has proved to be an effective pest controller, antifungal and larvicide when used alone and also in combination with different plant preparations (Kishore et al., 2015; Jandaik et al., 2015). Studies have shown that after photoactivation and purification, cow urine extract of $\mathbf{A}$. indica has been found to be effective against certain drug resistant bacterial strains like E. coli, K. pneumonia and multiple drug resistat S. aureus, P. aeruginosa and P. vulgaris (Randhawa et al., 2015).

The biochemical estimation of cow urine has shown that it contains sodium, nitrogen, sulphur, Vitamin A, B, C, D, E, minerals, manganese, iron, silicon, chlorine, magnesium, citric, succinic, calcium salts, phosphate, lactose, carbolic acid, enzymes, creatinine and hormones, 95\% part of original gomutra is water (Jeena et al., 2014). The total $\mathrm{N}$ in the cow urine ranges from 6.8 to $21.6 \mathrm{~g}$ litre ${ }^{-1}$. Distributional analysis of urinary nitrogen $(\mathrm{N})$ among various chemical constituents revealed $69 \%$ as urea, $7.3 \%$ as allantoin, $5.8 \%$ as hippuric acid, $3.7 \%$ as creatinine, $2.5 \%$ as creatine, $1.3 \%$ as uric acid, $0.5 \%$ as xanthine plus hypoxanthine, $1.3 \%$ as free amino acid $\mathrm{N}$ and $2.8 \%$ as ammonia (Bistow et al., 1992).

Corresponding Author: - Anil Kanaujia.

Address: - Ayurvet Research Foundation-Research and Development Centre, Village, Chidana, 
Consumption of cow urine is claimed to restore the balance of these substances and thus helps in curing from incurable diseases. In the rural villages in India, cow's urine is being used since a very long time as an effective antiseptic for wounds, skin problems, etc. (Jeena et al., 2014).

The cow urine market is estimated to be as big as $\$ 1$ billion (Economic Times, 2017). In India, there is demand of more than 5000 litres of distilled cow urine per day. While big players procure close to 10,000 litres of fresh cow urine daily, individual units procurement varies from 500 litres to 25,000 litres per month. Gomutra distillate is sold either pure or in combination with different herbs. As the cow urine distillate is mainly consumed as medicine to cure different ailments its quality and authenticity always remain questionable, hence a study was planned to compare the quality of in house prepared cow urine distillate with market available famous brand samples.

\section{Material and Method: -}

Commercial samples of distilled urine of cows were procured from Delhi and NCR. Fresh urine samples of indigenous and exotic cows were collected from village Chidana, district Sonepat, Haryana and distilled at ARF R\&D Centre laboratory using small distillation set up.

HPLC profiling of all the samples was carried on C-18 column using Agilent HPLC at lambda max $200 \mathrm{~nm}$, $\mathrm{pH}$ was carried out on EUTECH pH meter, TDS was calculated gravimetrically, Nitrogen was estimated using macro kjeldahl method, Phosphorus was done on SHIMADZU UVVIS spectrophotometer and Potassium was evaluated on HARRISON flame photometer.

\section{Result \& Discussion:-}

The original fresh indigenous cow urine samples were observed to be pale yellow in color, very strongly odoured with $0.47-0.55 \%$ nitrogen content, high TDS value $(43698-47654 \mathrm{ppm})$ indicated presence of very high salt contents, whereas Jersey cows' urine samples were observed to be light yellow in color, strongly odoured with 0.30 $0.39 \%$ nitrogen content and high TDS value (55700- 58097ppm).

The comparative study of distilled cow urine revealed that distillates produced in house were transparent and light odour with nitrogen content $0.012 \%-0.016 \%$ and $0.015 \%-0.017 \%$, respectively for indigenous and Jersey cows, whereas market available samples were light yellow to yellow in color and have light to strong urine odor with nitrogen content ranging from $0.014 \%-0.055 \%$. All the samples have an alkaline $\mathrm{pH}$ range of $7.50-8.59$, whereas phosphorus and potassium contents ranged from $0.0 \%-0.82 \%$ and $0.0 \%-1.30 \%$, respectively (Table 1). Fingerprint profile of all the samples on HPLC revealed 4-6 super imposable peaks of different area \%. Peak at RT 3.0 amounting to $70 \%-80 \%$ in original cow (indigenous and Jersey) urine was found to be common in all distilled samples, overlay of UV spectrum confirmed the presence of same compound. It was observed that conc. of the common compound is $4.5-6.0$ times less in in-house distilled urine than other samples.

Table 1:- Comparative analysis of cow urine distillates

\begin{tabular}{|c|c|c|c|c|c|c|c|c|c|}
\hline \multirow[t]{2}{*}{ S.N. } & \multirow[t]{2}{*}{ Parameter } & \multicolumn{8}{|c|}{ Samples } \\
\hline & & $\mathbf{A}^{\#}$ & $\mathbf{B}^{\#}$ & $\mathrm{C}^{\#}$ & $\mathbf{D}^{\#}$ & $\mathbf{E}$ & $\mathbf{F}$ & G & H \\
\hline 1 & Appearance & $\begin{array}{l}\text { Pale } \\
\text { yellow }\end{array}$ & $\begin{array}{l}\text { Light } \\
\text { yellow }\end{array}$ & $\begin{array}{l}\text { Like } \\
\text { water }\end{array}$ & $\begin{array}{l}\text { Like } \\
\text { water }\end{array}$ & $\begin{array}{c}\text { Slightly } \\
\text { yellowish }\end{array}$ & $\begin{array}{c}\text { Slightly } \\
\text { yellowish }\end{array}$ & Yellowish & $\begin{array}{c}\text { Slightly } \\
\text { yellowish }\end{array}$ \\
\hline 2 & Odour & $\begin{array}{c}\text { Very } \\
\text { strong } \\
\text { smell }\end{array}$ & $\begin{array}{c}\text { Strong } \\
\text { smell }\end{array}$ & $\begin{array}{l}\text { Light } \\
\text { smell }\end{array}$ & $\begin{array}{l}\text { Light } \\
\text { smell }\end{array}$ & $\begin{array}{l}\text { Light } \\
\text { smell }\end{array}$ & $\begin{array}{c}\text { Strong } \\
\text { smell }\end{array}$ & $\begin{array}{c}\text { Strong } \\
\text { smell }\end{array}$ & $\begin{array}{c}\text { Strong } \\
\text { smell }\end{array}$ \\
\hline 3 & $\mathrm{pH}$ & $\begin{array}{l}8.15- \\
8.43\end{array}$ & $\begin{array}{l}7.50- \\
7.82\end{array}$ & $\begin{array}{l}7.93- \\
8.09\end{array}$ & $\begin{array}{l}8.11- \\
8.31\end{array}$ & 8.22 & 8.01 & 8.29 & 8.59 \\
\hline 4 & TDS (ppm) & $\begin{array}{r}43698 \\
47654 \\
\end{array}$ & $\begin{array}{l}55700- \\
58097 \\
\end{array}$ & $\begin{array}{c}140- \\
178 \\
\end{array}$ & $\begin{array}{c}160- \\
180 \\
\end{array}$ & 182 & 560 & 1110 & 198 \\
\hline 5 & $\begin{array}{l}\text { Nitrogen } \\
(\%)\end{array}$ & $\begin{array}{c}0.47- \\
0.55\end{array}$ & $\begin{array}{c}0.30- \\
0.39\end{array}$ & $\begin{array}{l}0.012- \\
0.016\end{array}$ & $\begin{array}{c}0.015- \\
0.017\end{array}$ & 0.014 & 0.019 & 0.055 & 0.014 \\
\hline 6 & $\begin{array}{l}\text { Phosphorus } \\
(\%)\end{array}$ & 0.00 & 0.82 & 0.00 & 0.00 & 0.00 & 0.00 & 0.00 & 0.00 \\
\hline 7 & $\begin{array}{l}\text { Potassium } \\
(\%)\end{array}$ & 0.85 & 1.30 & 0.00 & 0.00 & 0.0008 & 0.002 & 0.0003 & 0.003 \\
\hline
\end{tabular}


Legends : Samples, A- Indigenous cow urine - original, B- Jersey cow urine, C - In house prepared indigenous cow urine distillate, D- In house prepared Jersey cow urine distillate, E- H - Commercially available cow urine distillate samples. ${ }^{n}=3$

\section{Conclusion:-}

Comparative study of different parameters to assess the quality of commercial available samples of distilled urine of cows and in house prepared revealed that market available samples are authentic but not properly distilled or photo degraded or the original cow urine is diluted with the water to make them look like distilled one. Looking at the therapeutic potential of the cow urine / distillates and menace of AMR (antimicrobial resistance) further studies shall be carried out to find out its potential on its own or medicinal plants (with potential antimicrobial activity) extracts prepared using it as solvent, against drug resistant bacteria.

\section{References:-}

1. Kishore, S., Rao, L., Ramesh, B., Aditya, A.K. (2015): Indian cow urine distillation and therapeutic uses. Mintage journal of pharmaceutical and medical sciences, 4(1), 1-5.

2. Singla, S., Kaur, S. (2016): Biological activities of cow urine: an ayurvedic elixir. European journal of pharmaceutical and medical research, 3(4), $118-124$.

3. Mohanty, I., Senapati, 3. Jandaik, S., Thakur, P., Kumar, V. (2015): Efficacy of cow urine as plant growth enhancer and antifungal agent. Advances in agriculture, 1-7.

4. Randhawa, G.K., Sharma, R. Chemotherapeutic potential of cow urine: A review. (2015): J Intercult Ethnopharmacol, 4(2), $180-186$.

5. M.R., Jeena, D., Palai, S. (2014): Diversified uses of cow urine. International Journal of Pharmacy and Pharmaceutical Sciences, 6(3), 20- 22.

6. Bistow, A.W., Whitehead, D.C., Cockburn, J.E. (1992): Nitrogenous constituents in the urine of cattle, sheep and goats. Journal of the Scienec, Food and Agriculture, 59(3), 387- 394.

7. Economic Times (2017): Brand Equity, Feb. 08. 